\title{
MLLT1 Gene Mutation
}

National Cancer Institute

\section{Source}

National Cancer Institute. MLLT1 Gene Mutation. NCI Thesaurus. Code C158671.

A change in the nucleotide sequence of the MLLT1 gene. 